\title{
Integrasi Database M-Learning (Mobile Learning) Menggunakan Content Manajemen System Moodle Untuk Pengelolaan Konten Akademik
}

\author{
${ }^{1}$ Ade Andri Hendriadi., ${ }^{2}$ Deden Wahiddin \\ ${ }^{1}$ Universitas Singaperbangsa Karawang \\ ${ }^{2}$ Universitas Buana Perjuangan Karawang \\ ${ }^{1}$ ade.andri@staff.unsika.ac.id, ${ }^{2}$ deden.wahiddin@ubpkarawang.ac.id \\ ${ }^{1}$ Jl. H. S. Ronggowaluyo Telukjambe Timur Karawang 41361 \\ ${ }^{2}$ Jl. H. S. Ronggowaluyo Telukjambe Timur Karawang 41361
}

\begin{abstract}
Abstrak
Pengembangkan aplikasi m-learning (mobile learning) yang terintegrasi dengan sebuah LMS (Learning Management System) Moodle dan untuk kemudian diimplementasikan sebagai fasilitas pendukung perkuliahan. Tahapan penelitian menggunakan metode pengembangan perangkat lunak SDLC (Software Development Life Cycle) dengan model USDP (Unified Software Development Process). Aplikasi m-learning yang dikembangkan pada penelitian ini bersifat client yang penggunaanya lebih ditujukan untuk mahasiswa (student). Aplikasi yang dikembangkan berjalan pada platform android. Penulisan kode program menggunakan bahasa pemrograman Java menggunakan IDE Eclipse. Pengembangan aplikasi juga menggunakan beberapa Development tools diantaranya Android SDK (Software Development Kit) dan ADT (Android Development Tools) sebagai alat bantu berupa emulator android. Proses integrasi antara LMS Moodle dengan aplikasi m-learning menggunakan bahasa pemrograman PHP (HyperText Preprocessor). Dari hasil implementasi yang dilakukan aplikasi m-learning dinilai baik untuk digunakan sebagai fasilitas pendukung belajar dalam perkuliahan
\end{abstract}

Keywords: Mobile learning, Moodle LMS, USDP

\section{Latar Belakang}

Perkembangan teknologi informasi saat ini sangat berperan penting dalam hampir setiap sektor kehidupan manusia. Perkembangan tersebut mengarah kepada kecanggihan teknologi Smartphone yang mampu meniru kecerdasan yang dimiliki oleh sebuah komputer.

Salah satu sistem operasi mobile yang digunakan oleh smartphone adalah android. Berdasarkan beberapa hasil lembaga survey menunjukan bahwa saat ini perkembangan penggunaan sistem operasi android pada smartphone mengalami tren meningkat jika dibandingkan dengan sistem operasi smartphone lainnya. Berikut adalah data yang diperoleh dari lembaga survey http://gs.statcounter.com hingga bulan Februari 2011.

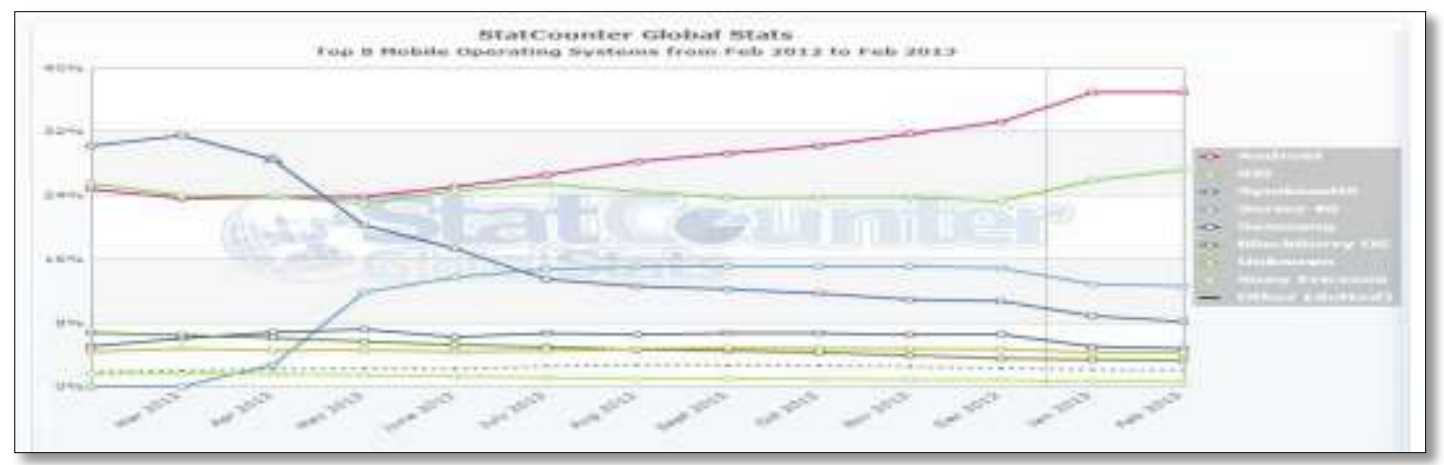

Gambar 1.1. Grafik sistem operasi mobile paling populer di dunia. 


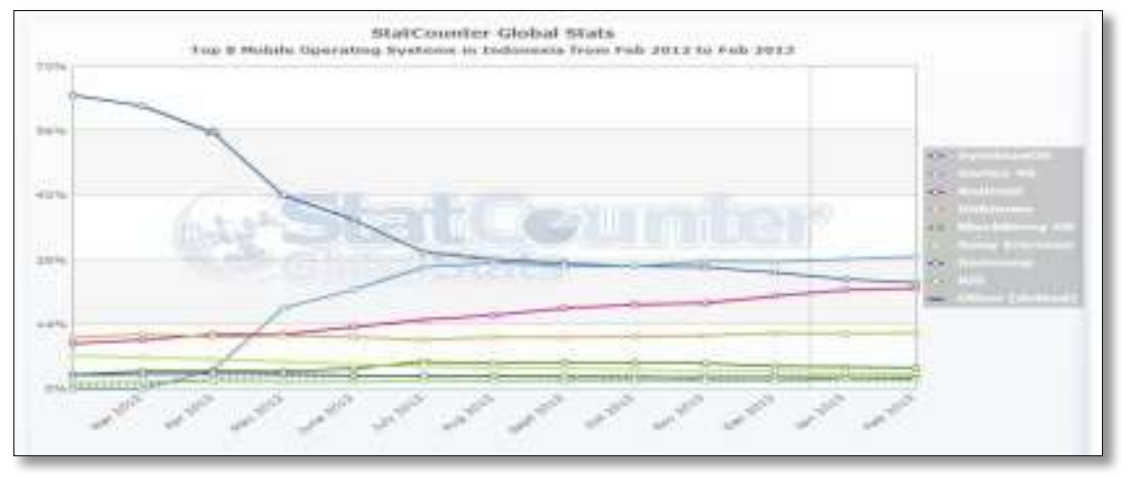

Gambar 1.2. Grafik sistem operasi mobile paling populer di Indonesia.

Sebagai bahan referensi lainnya, peneliti telah melakukan survey awal tentang sistem operasi mobile yang digunakan oleh mahasiswa Fakultas Ilmu Komputer (Fasilkom) Universitas Singaperbangsa Karawang (Unsika) sebagai objek penelitian. (Pengambilan data pada bulan maret 2013).

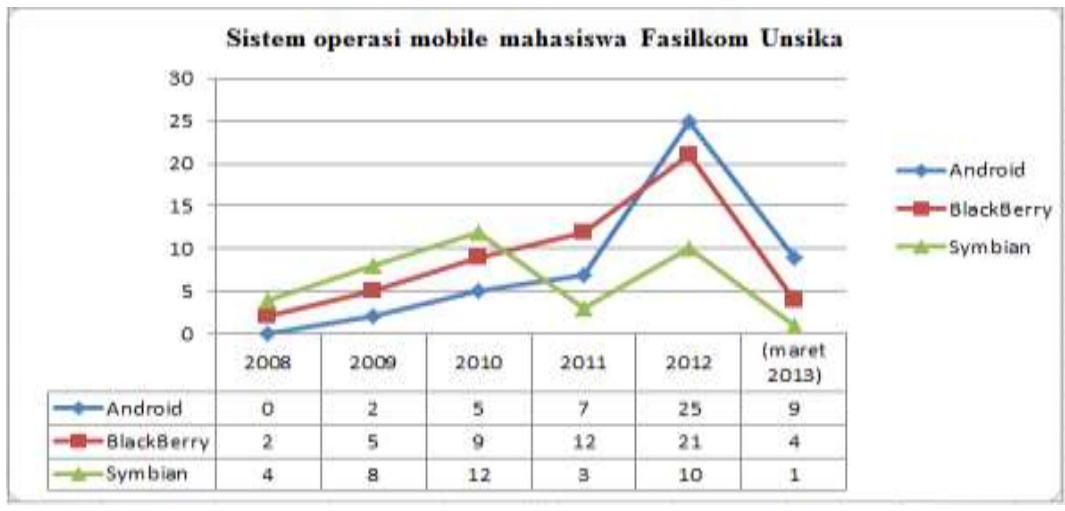

Gambar 1.3. Sistem operasi mobile mahasiswa Fasilkom Unsika.

Perkembangan teknologi informasi yang pesat juga dapat dimanfaatkan dalam mengembangkan berbagai bidang kehidupan, diantaranya adalah dalam bidang pendidikan. Salah satu pengembangan dalam proses pendidikan yang bisa diterapkan adalah konsep E-learning (Electronic learning). Proses pembelajaran menggunakan konsep e-learning saat ini banyak dibantu oleh berbagai LMS (Learning Management System) yang berperan sebagai tools atau alat pembangun website e-learning. LMS yang saat ini banyak digunakan adalah moodle LMS. berdasarkan data yang diperoleh dari situs resmi moodle yaitu https://moodle.org, di Indonesia saat ini (maret 2013) ada sekitar 1540 website e-learning yang dibangun menggunakan LMS moodle.

Mengusung konsep dasar e-learning dan didukung oleh kemampuan mobilitas yang tinggi dalam konsep m-learning, pemanfaatan teknologi informasi dalam dunia pendidikan akan semakin terasa manfaatnya dalam memberikan kemudahan dan memaksimalkan proses belajar mengajar.

\section{Landasan Teori}

\subsection{Mobile Learning (M-Learning)}

M-learning didefinisikan oleh Clark Quinn (2000) sebagai :

" The intersection of mobile computing and e-learning: accessible resources wherever you are, strong search capabilities, rich interaction, powerful support for effective learning, and performance-based assessment. ELearning independent of location in time or space."

\subsection{Moodle}

Moodle adalah sebuah Content Management System (CMS) - paket software yang dirancang untuk membantu pendidik membuat media belajar online yang berkualitas dan mengelola hasil belajar. 


\subsection{Android}

Menurut Nazaruddin Safaat H (2012), android adalah sebuah sistem operasi untuk perangkat mobile berbasis linux yang mencakup sistem operasi, middleware dan aplikasi. Android menyediakan platform terbuka bagi para pengembang untuk menciptakan aplikasi mereka.

\section{Pembahasan}

Tahapan penelitian menggunakan metode pengembangan perangkat lunak SDLC (Software Development Life Cycle) dengan model USDP (Unified Software Development Process). USDP merupakan proses pengembangan sistem yang berkelanjutan, dimana masing-masing bagian dilakukan secara iteratif mulai dari tahap analisis, perancangan, deployment, implementasi dan pengujian. Dalam hal ini, USDP menggunakan diagram-diagram UML yang sesuai dengan fungsinya masing-masing.

\subsection{Analisis}

Tahap pertama alur penelitian menggunakan metode USDP yang dilakukan adalah tahap analisis. Tahap analisis dalam penelitian ini melakukan analisis terhadap masalah, kebutuhan software dan pengguna software.

\subsubsection{Pendefinisian Masalah}

Sebagian mahasiswa Fasilkom merupakan pegawai/karyawan perusahaan yang tentu saja dalam proses belajar memiliki waktu yang terbatas karena harus membagi waktu antara kuliah dan bekerja.

Salah satu solusi atau pemecahan dari masalah tersebut adalah mengembangkan metode belajar menggunakan konsep e-learning. Namun konsep e-learning biasa masih terbatas pada device yang digunakan berupa PC/laptop yang tidak mempunyai mobilitas yang tinggi seperti mobile phone.

\subsubsection{Pendefinisian Kebutuhan Software}

Sistem yang bisa dikembangkan sebagai alternatif penyelesaian masalah di atas adalah menggabungkan mobilitas tinggi dari mobile phone dengan konsep belajar e-learning yang saat ini dikenal dengan istilah $m$ learning (mobile learning), sehingga dengan konsep mobile learning ini kita bisa belajar kapanpun dan dimanapun.

\subsubsection{Pendefinisian Pengguna Software}

Pada penelitian ini, aplikasi yang dibuat lebih menitikberatkan pada sisi client, sehingga aplikasi yang dibuat nantinya akan lebih diimplementasikan oleh mahasiswa sebagai user.

Fasilitas yang didapatkan oleh mahasiswa sebagai client/user adalah :

1. Melihat isi materi text

2. Mengunduh/download file materi

3. Melihat tugas

4. Entri dan update tugas

5. Melihat nilai tugas

6. Melihat berita/informasi

7. Melihat kontak user

\subsection{Perancangan}

Dengan pemodelan USDP yang berorientasi objek, perancangan dan desain perangkat lunak menggunakan beberapa diagram UML sesuai dengan fungsinya masing-masing.

\subsubsection{Diagram Use case}

Use case atau diagram use case merupakan pemodelan untuk kelakuan (behaviour) sistem informasi yang akan dibuat. Use case mendeskripsikan sebuah interaksi antara satu atau lebih aktor dengan sistem informasi yang akan dibuat.

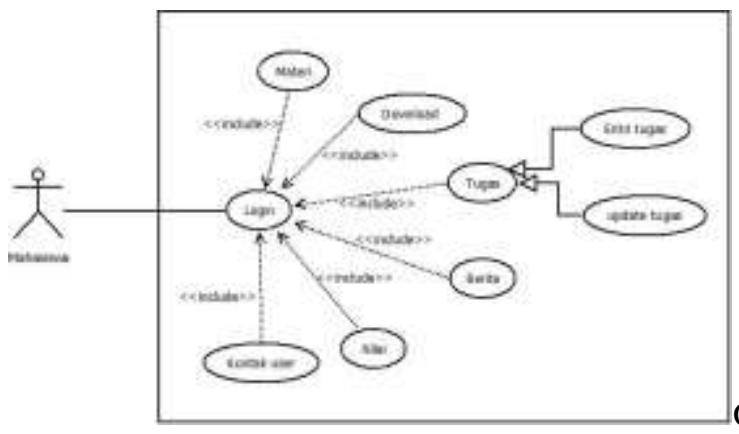

Gambar 3.1. Diagram use case aplikasi mobile learning. 


\subsubsection{Diagram Kelas}

Diagram kelas atau class diagram menggambarkan struktur sistem dari segi pendefinisian kelas-kelas yang akan dibuat untuk membangun sistem.

Kelas memiliki apa yang disebut atribut dan metode atau operasi.

1. Atribut merupakan variabel-variabel yang dimiliki oleh suatu kelas

2. Operasi atau metode adalah fungsi-fungsi yang dimiliki oleh suatu kelas

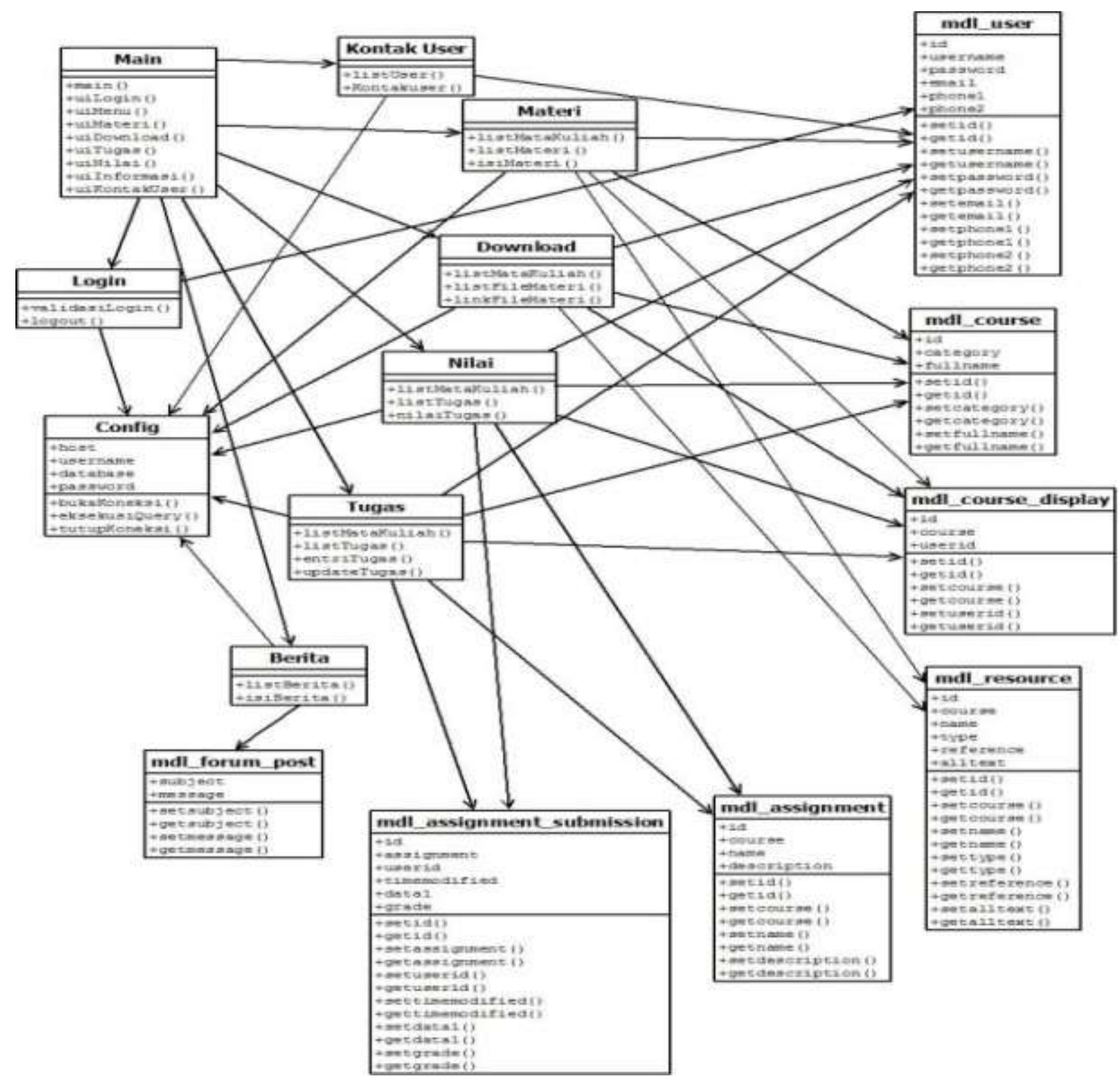

Gambar 3.2. Diagram kelas aplikasi mobile learning 


\subsubsection{Diagram sekuen}

Diagram sekuen menggambarkan kelakuan objek pada use case dengan mendeskripsikan waktu hidup objek dan message yang dikirimkan dan diterima objek.

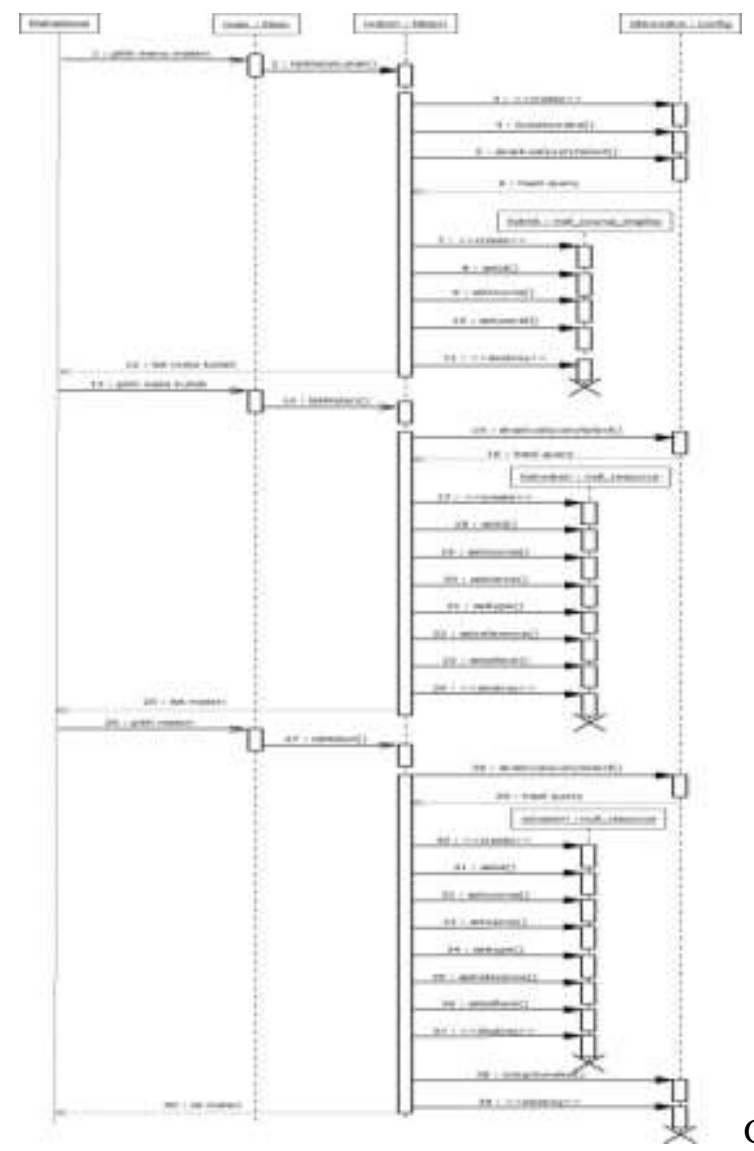

Gambar 3.3. Diagram sekuen aplikasi mobile learning

\subsubsection{Diagram Aktivitas}

Diagram aktivitas atau activity diagram menggambarkan workflow (aliran kerja) atau aktivitas dari sebuah sistem atau proses bisnis.

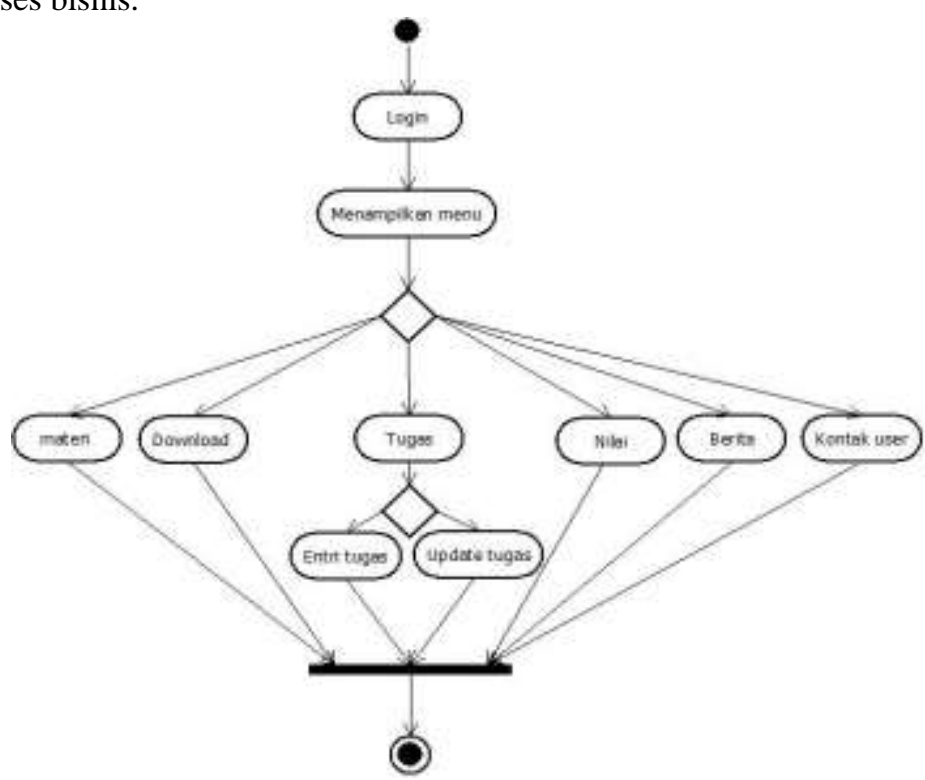

Gambar 3.4. Diagram aktivitas aplikasi mobile learning 


\subsubsection{Desain Interface}

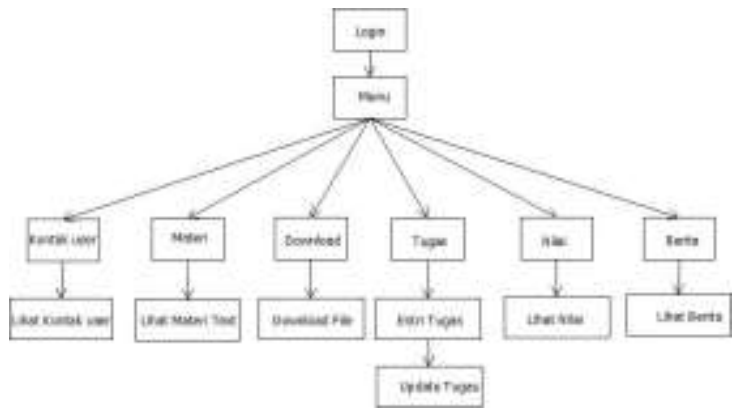

Gambar 3.6. Diagram struktur menu

\subsection{Deployment}

Model deployment menggunakan Diagram deployment atau deployment diagram yang menunjukan konfigurasi komponen dalam proses eksekusi aplikasi.

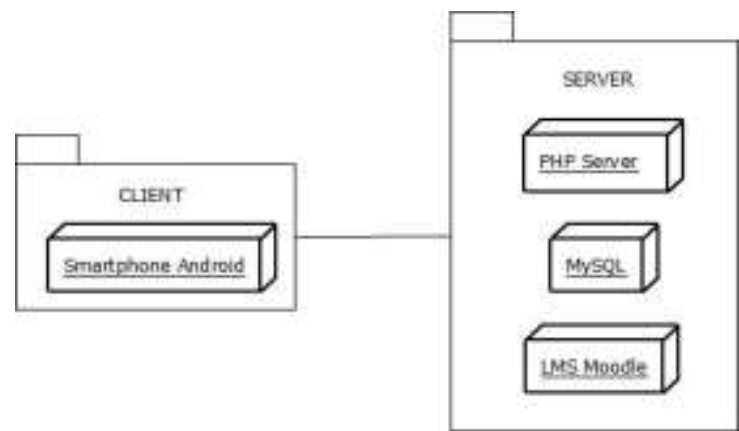

Gambar 3.5. Diagram deployment aplikasi mobile learning

\subsection{Implementasi}

Implementasi kode program yang dibuat untuk membangun aplikasi m-learning ini terbagi menjadi 3 bagian, yaitu :

1. Source code *.xml

Source code *.xml berfungsi sebagai penangan tampilan atau interface aplikasi.

2. $\quad$ Source code *.java

Source code *.java berfungsi sebagai penangan aksi dari setiap tampilan.

3. Source code*.php

Source code *.php berfungsi sebagai penghubung antara aplikasi (client) dengan database (server)

Implementasi dilakukan pada emulator android dan mobile phone berbasis android.

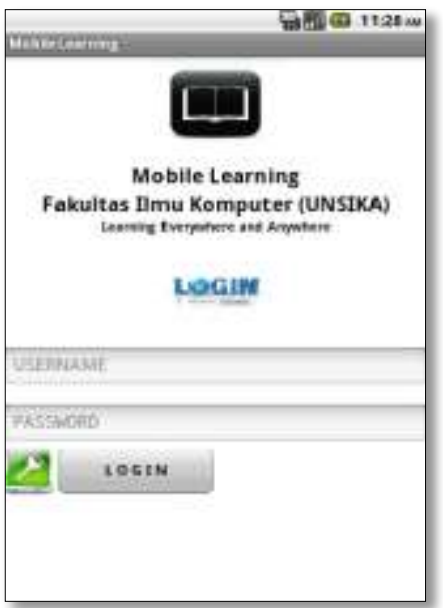

Gambar 3.7. Form login aplikasi mobile learning 


\subsection{Pengujian}

Setelah pembuatan kode program selesai, langkah selanjutnya adalah melakukan pengujian terhadap aplikasi yang telah dibuat. Dalam penelitian ini penulis melakukan dua jenis pengujian yaitu Black Box Testing dan White Box Testing.

\section{Black box testing}

Unit tes : Login dan logout

Tabel 3.1. Pengujian black box unit tes login dan logout.

\begin{tabular}{|c|l|l|l|}
\hline No. & \multicolumn{1}{|c|}{ Input } & \multicolumn{1}{|c|}{$\begin{array}{c}\text { Hasil yang } \\
\text { diharapkan }\end{array}$} & $\begin{array}{l}\text { Hasil } \\
\text { Uji }\end{array}$ \\
\hline 1. & $\begin{array}{l}\text { Username dan } \\
\text { password benar } \\
\text { (klik tombol login) }\end{array}$ & Tampil menu utama & Ok \\
\hline 2. & $\begin{array}{l}\text { Username / } \\
\text { password salah atau } \\
\text { keduanya salah (klik } \\
\text { tombol login) }\end{array}$ & $\begin{array}{l}\text { Tampil pesan tidak } \\
\text { valid }\end{array}$ & Ok \\
\hline 3. & Klik tombol logout & $\begin{array}{l}\text { Tampil interface } \\
\text { login }\end{array}$ & Ok \\
\hline
\end{tabular}

2. White box testing

Unit tes : Login

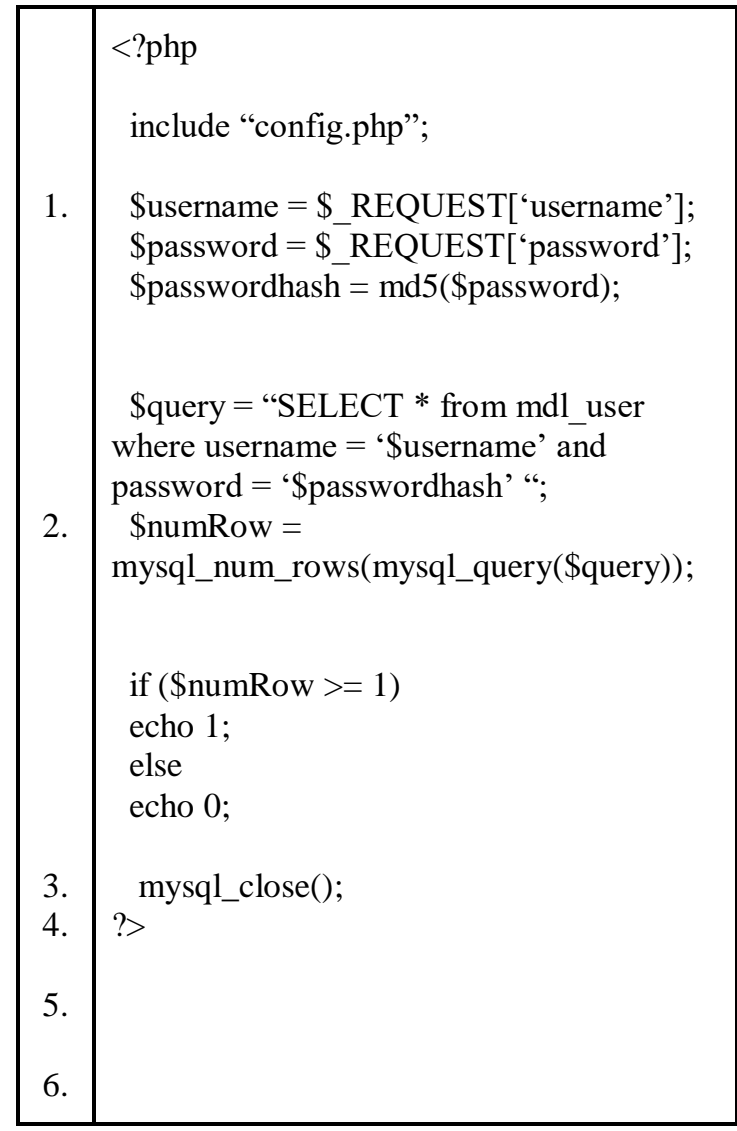




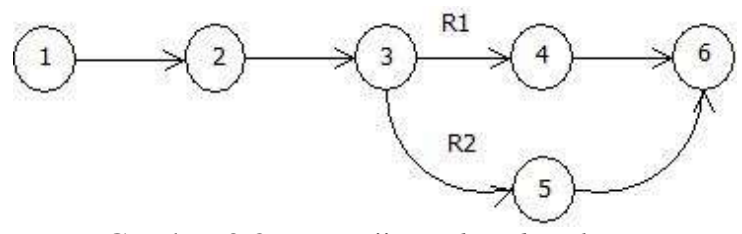

Gambar 3.8. Pengujian white box login

$\mathrm{V}(\mathrm{G})=\mathrm{E}-\mathrm{N}+2=6-6+2=2$

$\mathrm{V}(\mathrm{G}) \quad=\mathrm{P}+1=1+1=2$

$\mathrm{V}(\mathrm{G}) \quad=\mathrm{R}=2$

Alur (Path) yang mungkin dilalui :

$\mathrm{P}(1)=1-2-3-4-6$

$\mathrm{P}(2) \quad=1-2-3-5-6$

\section{Uji coba aplikasi}

Uji coba aplikasi mobile learning dilakukan di Fasilkom Unsika dengan jumlah sample user sebanyak 25 orang mahasiswa yang diambil secara purposive dari angkatan 2009 - 2012. Terdapat 3 aspek yang menjadi tolak ukur kelayakan aplikasi yang telah dibuat, yaitu : desain tampilan, fungsi konten / fitur, dan kegiatan pembelajaran.

Tabel 4.1. Hasil penilaian aspek desain tampilan

\begin{tabular}{|c|c|c|c|c|c|c|c|}
\hline \multirow{2}{*}{ Indikator } & \multirow{2}{*}{$\begin{array}{l}\mathrm{f} / \\
\%\end{array}$} & \multicolumn{5}{|c|}{ Skor } & \multirow{2}{*}{ Total } \\
\hline & & 5 & 4 & 3 & 2 & 1 & \\
\hline \multirow[b]{2}{*}{$\begin{array}{l}\text { Struktur / urutan tampilan } \\
\text { menu jelas }\end{array}$} & $\mathrm{f}$ & 1 & 16 & 7 & 1 & 0 & 25 \\
\hline & $\%$ & $4 \%$ & $64 \%$ & $\begin{array}{l}28 \\
\%\end{array}$ & $4 \%$ & $0 \%$ & $100 \%$ \\
\hline \multirow[b]{2}{*}{$\begin{array}{l}\text { Fungsi setiap menu mudah } \\
\text { dimengerti }\end{array}$} & $\mathrm{f}$ & 2 & 13 & 10 & 0 & 0 & 25 \\
\hline & $\%$ & $8 \%$ & $52 \%$ & $\begin{array}{l}40 \\
\%\end{array}$ & $0 \%$ & $0 \%$ & $100 \%$ \\
\hline \multirow[b]{2}{*}{ Desain tampilan menarik } & $\mathrm{f}$ & 4 & 11 & 9 & 1 & 0 & 25 \\
\hline & $\%$ & $16 \%$ & $44 \%$ & $\begin{array}{l}36 \\
\%\end{array}$ & $4 \%$ & $0 \%$ & $100 \%$ \\
\hline \multirow{2}{*}{$\begin{array}{l}\text { Sesuai dengan karakteristik } \\
\text { tingkatan pengguna } \\
\text { (mahasiswa) }\end{array}$} & $\mathrm{f}$ & 6 & 11 & 7 & 1 & 0 & 25 \\
\hline & $\%$ & $24 \%$ & $44 \%$ & $\begin{array}{l}28 \\
\%\end{array}$ & $4 \%$ & $0 \%$ & $100 \%$ \\
\hline Total skor & $\mathrm{f}$ & 13 & 51 & 33 & 3 & 0 & 100 \\
\hline Persentase & $\%$ & $13 \%$ & $51 \%$ & $\begin{array}{l}33 \\
\%\end{array}$ & $3 \%$ & $0 \%$ & $100 \%$ \\
\hline
\end{tabular}

Tabel 4.2. Hasil penilaian aspek fungsi konten/fitur

\begin{tabular}{|c|c|c|c|c|c|c|c|}
\hline \multirow{2}{*}{ Indikator } & \multirow{2}{*}{$\mathrm{f} / \%$} & \multicolumn{5}{|c|}{ Skor } & \multirow{2}{*}{ Total } \\
\hline & & 5 & 4 & 3 & 2 & 1 & \\
\hline \multirow{2}{*}{$\begin{array}{l}\text { Mempermudah melihat dan } \\
\text { memperoleh materi }\end{array}$} & $\mathrm{f}$ & 3 & 12 & 9 & 0 & 1 & 25 \\
\hline & $\%$ & $12 \%$ & $48 \%$ & $36 \%$ & $0 \%$ & $4 \%$ & $100 \%$ \\
\hline \multirow{2}{*}{ Mempermudah mengerjakan tugas } & $\mathrm{f}$ & 3 & 10 & 11 & 1 & 0 & 25 \\
\hline & $\%$ & $12 \%$ & $40 \%$ & $44 \%$ & $4 \%$ & $0 \%$ & $100 \%$ \\
\hline \multirow{2}{*}{ Mempermudah melihat nilai } & $\mathrm{f}$ & 4 & 14 & 6 & 1 & 0 & 25 \\
\hline & $\%$ & $16 \%$ & $56 \%$ & $24 \%$ & $4 \%$ & $0 \%$ & $100 \%$ \\
\hline \multirow{2}{*}{ Mempermudah melihat informasi } & $\mathrm{f}$ & 4 & 16 & 5 & 0 & 0 & 25 \\
\hline & $\%$ & $16 \%$ & $64 \%$ & $20 \%$ & $0 \%$ & $0 \%$ & $100 \%$ \\
\hline \multirow{2}{*}{ Mempermudah melihat info kontak } & $\mathrm{f}$ & 5 & 17 & 2 & 1 & 0 & 25 \\
\hline & $\%$ & $20 \%$ & $68 \%$ & $8 \%$ & $4 \%$ & $0 \%$ & $100 \%$ \\
\hline Total skor & $\mathrm{f}$ & 19 & 69 & 33 & 3 & 1 & 125 \\
\hline Persentase & $\%$ & $\begin{array}{c}15,2 \\
\%\end{array}$ & $\begin{array}{c}55,2 \\
\%\end{array}$ & $\begin{array}{c}26,4 \\
\%\end{array}$ & $2,4 \%$ & $0,8 \%$ & $100 \%$ \\
\hline
\end{tabular}


Tabel 4.3. Hasil penilaian aspek kegiatan pembelajaran

\begin{tabular}{|c|c|c|c|c|c|c|c|}
\hline \multirow{2}{*}{ Indikator } & \multirow{2}{*}{$\mathrm{f} / \%$} & \multicolumn{5}{|c|}{ Skor } & \multirow{2}{*}{ Total } \\
\hline & & 5 & 4 & 3 & 2 & 1 & \\
\hline \multirow{2}{*}{$\begin{array}{l}\text { Menjadi fasilitas pendukung dalam } \\
\text { perkuliahan }\end{array}$} & $\mathrm{f}$ & 1 & 16 & 7 & 0 & 1 & 25 \\
\hline & $\%$ & $4 \%$ & $64 \%$ & $28 \%$ & $0 \%$ & $4 \%$ & $100 \%$ \\
\hline \multirow{2}{*}{$\begin{array}{l}\text { Konsep belajar simpel menggunakan } \\
\text { perangkat mobile }\end{array}$} & $\mathrm{f}$ & 1 & 15 & 8 & 1 & 0 & 25 \\
\hline & $\%$ & $4 \%$ & $60 \%$ & $32 \%$ & $4 \% \%$ & $0 \%$ & $100 \%$ \\
\hline \multirow{2}{*}{$\begin{array}{l}\text { Meningkatkan mobilitas belajar } \\
\text { (dimanapun dan kapanpun) }\end{array}$} & $\mathrm{f}$ & 4 & 15 & 6 & 0 & 0 & 25 \\
\hline & $\%$ & $16 \%$ & $60 \%$ & $24 \%$ & $0 \%$ & $0 \%$ & $100 \%$ \\
\hline Total skor & $\mathrm{f}$ & 6 & 46 & 21 & 1 & 1 & 75 \\
\hline Persentase & $\%$ & $8 \%$ & $\begin{array}{c}61,4 \\
\%\end{array}$ & $28 \%$ & $1,3 \%$ & $1,3 \%$ & $100 \%$ \\
\hline
\end{tabular}

Tabel 4.4. Rekapitulasi skor 3 aspek indikator penilaian

\begin{tabular}{|c|c|c|c|c|}
\hline $\begin{array}{c}\text { Skor } \\
(x i)\end{array}$ & $\begin{array}{c}\text { Desain Tampilan } \\
(f i)\end{array}$ & $\begin{array}{c}\text { Fungsi Konten/Fitur } \\
(f i)\end{array}$ & $\begin{array}{c}\text { Pembelajaran } \\
(f i)\end{array}$ & $\sum$ fixi \\
\hline 5 & 13 & 19 & 6 & 190 \\
\hline 4 & 51 & 69 & 46 & 664 \\
\hline 3 & 33 & 33 & 21 & 261 \\
\hline 2 & 3 & 3 & 1 & 14 \\
\hline 1 & 0 & 1 & & 2 \\
\hline \multicolumn{4}{|r|}{ Total skor } & 94,25 \\
\hline
\end{tabular}

Tahap selanjutnya untuk menghitung rating scale pada tabel interpretasi skor hasil penilaian bisa menggunakan rumus :

$$
\begin{aligned}
& R s=\frac{n(m-1)}{m} \\
& \text { Keterangan }: \\
& R s=\text { Rating scale } \\
& n=\text { Jumlah responden } \\
& m=\text { Skor tertinggi }
\end{aligned}
$$

Maka, rating scale untuk skor hasil penilaian aplikasi ini adalah :

$$
\begin{aligned}
R s & =\frac{n(m-1)}{m} \\
R s & =\frac{25(5-1)}{5} \\
R s & =\frac{25(4)}{5} \\
R s & =\frac{100}{5} \\
R s & =20
\end{aligned}
$$

Tabel 4.5. Interpretasi skor hasil penilaian

\begin{tabular}{|c|c|}
\hline Skor & Interpretasi \\
\hline $25-45$ & Tidak baik \\
\hline $46-65$ & Kurang baik \\
\hline $66-85$ & Cukup \\
\hline $86-105$ & Baik \\
\hline $106-125$ & Sangat Baik \\
\hline
\end{tabular}

Berdasarkan hasil tabel rekapitulasi, rata-rata skor yang didapatkan adalah sebesar 94,25. Angka tersebut berada diantara skor 86 - 105 yang berarti aplikasi ini dinilai "BAIK" oleh responden. 
Jika digambarkan dalam sebuah skala kategori, hasil penilaian aplikasi ini adalah :

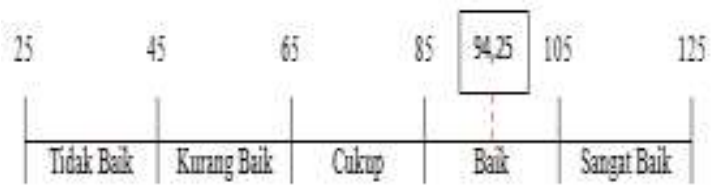

Gambar 4.1. Skala kategori skor penilaian aplikasi

\section{Kesimpulan dan Saran}

5.1. Kesimpulan adalah :

Berdasarkan hasil analisis dan pengujian yang telah dilakukan, maka kesimpulan dari penelitian ini

1. Pengaksesan fitur-fitur utama LMS moodle melalui perangkat smartphone berbasis android dilakukan dengan cara membuat sebuah aplikasi mobile learning berbasis android yang terintegrasi langsung dengan database moodle. Integrasi yang terjadi hanya antara aplikasi mobile learning dan database moodle dan tidak melibatkan fungsional LMS moodle secara keseluruhan.

2. Mengintegrasikan LMS moodle dengan aplikasi mobile learning menggunakan bahasa pemrograman PHP sebagai penghubung antara aplikasi dengan database.

3. Hasil uji coba aplikasi menyatakan bahwa aplikasi mobile learning dinilai "BAIK" diimplementasikan dalam proses perkuliahan sebagai fasilitas pendukung untuk memaksimalkan kegiatan belajar mengajar dalam proses perkuliahan. Dengan aplikasi mobile learning diharapkan dapat membantu mahasiswa untuk belajar kapanpun dan dimanapun.

\subsection{Saran}

Berdasarkan hasil kesimpulan diatas, maka saran-saran yang dapat dikemukakan adalah : Bagi peneliti selanjutnya :

1. Fungsi setiap fitur LMS moodle dalam aplikasi ini masih bersifat sederhana, sehingga fitur yang sudah ada bisa dilakukan pengembangan lebih lanjut.

2. Beberapa fasilitas LMS moodle yang belum terdapat pada aplikasi ini bisa ditambahkan untuk melengkapi fitur yang sudah ada.

\section{Daftar Pustaka}

Nazruddin Safaat H. (2012). Pemrograman Aplikasi Mobile Smartphone dan Tablet PC Berbasis Android. Penerbit Informatika. Bandung. ISBN : 978-602-8758-52-9.

Nugroho, Adi. (2010). Rekayasa Perangkat Lunak Berorientasi Objek dengan Metode USDP (Unified Software Development Process). Penerbit Andi. Yogyakarta. ISBN : 978-979-29-1503-7.

Quinn, C. (2000). MLearning : Mobile, Wireless, In-Your-Pocket-Learning. [Online].

Tersedia : http://www.linezine.com/2.1/features/cqmmwiyp.htm Diakses tanggal : 22 maret 2013

Shalahudin, M. \& Rosa A. S. (2011). Modul Pembelajaran Rekayasa Perangkat Lunak (Terstruktur dan Berorientasi Objek). Penerbit Modula. Bandung. ISBN : 978-602-8759-13-7.

http://moodle.org diakses tanggal : 21 maret 2013

http://gs.statcounter.com diakses tanggal : 21 maret 2013 